\title{
Association of serum 25-hydroxyvitamin D with metabolic syndrome and type 2 diabetes: a one sample Mendelian randomization study
}

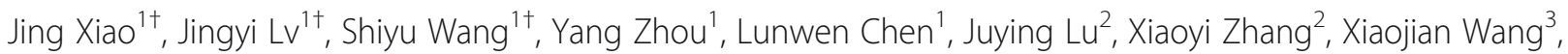
Yunjuan $\mathrm{Gu}^{2^{*}}$ and Qingyun Lu ${ }^{1 *}$

\begin{abstract}
Background: Vitamin D deficiency has been associated with type 2 diabetes (T2D) and metabolic syndrome (MS) and its components. However, it is unclear whether a low concentration of vitamin $D$ is the cause or consequence of these health conditions. Thus, this study aimed to evaluate the association of vitamin D concentrations and its genetic risk scores (GRSs) with MS and its component diseases, such as T2D, in middle-aged and elderly participants from rural eastern China.

Methods: A subset of 2393 middle-aged and elderly individuals were selected from 70,458 participants of the Nantong Chronic Diseases Study of 2017-2018 in China. We used two 25-hydroxyvitamin D (25[OH]D) synthesis single-nucleotide polymorphisms (SNPs) (DHCR7-rs12785878 and CYP2R1-rs10741657) and two 25(OH) D metabolism SNPs (GC-rs2282679 and CYP24A1-rs6013897) for creating GRSs, which were used as instrumental variables to assess the effect of genetically lowered $25(\mathrm{OH}) \mathrm{D}$ concentrations on MS and T2D based on the Wald ratio. F statistics were used to validate that the four SNPs genetically determined $25(\mathrm{OH}) \mathrm{D}$ concentrations.

Results: Compared to vitamin D sufficient individuals, individuals with vitamin D insufficiency had an odds ratio (OR [95\% confidence interval \{Cl\}]) of MS of $1.30(1.06-1.61)$ and of T2D of $1.32(1.08-1.64)$, individuals with vitamin D deficiency had an ORs (95\% CI) of MS of $1.50(1.24-1.79)$ and of T2D of $1.47(1.12-1.80)$, and those with vitamin D severe deficiency had an ORs (95\% Cl) of MS of 1.52 (1.29-1.85) and of T2D of 1.54 (1.27-1.85). Mendelian randomization analysis showed a $25-\mathrm{nmol} / \mathrm{L}$ decrease in genetically instrumented serum $25(\mathrm{OH}) \mathrm{D}$ concentrations using the two synthesis SNPs (DHCR7 and CYP2R1 genes) associated with the risk of T2D and abnormal diastolic blood pressure (DBP) with ORs of 1.10 (95\%Cl: 1.02-1.45) for T2D and 1.14 (95\%Cl: 1.03-1.43) for DBP.
\end{abstract}

\footnotetext{
*Correspondence: qingyun79@126.com; desette@ntu.edu.cn

${ }^{\dagger}$ Jing Xiao, Jingyi Lv and Shiyu Wang contributed equally to this work.

${ }^{2}$ Department of Endocrinology and Metabolism, Affiliated Hospital of

Nantong University, No.20 Xisi Road, Chongchuan District, Nantong, Jiangsu,

P.R. China 226001

'Department of Epidemiology and Medical Statistics, School of Public Health,

Nantong University, No.9 Seyuan Road, Chongchuan District, Nantong,

Jiangsu, P.R. China 226019

Full list of author information is available at the end of the article
}

(c) The Author(s). 2021 Open Access This article is licensed under a Creative Commons Attribution 4.0 International License, which permits use, sharing, adaptation, distribution and reproduction in any medium or format, as long as you give appropriate credit to the original author(s) and the source, provide a link to the Creative Commons licence, and indicate if changes were made. The images or other third party material in this article are included in the article's Creative Commons licence, unless indicated otherwise in a credit line to the material. If material is not included in the article's Creative Commons licence and your intended use is not permitted by statutory regulation or exceeds the permitted use, you will need to obtain permission directly from the copyright holder. To view a copy of this licence, visit http://creativecommons.org/licenses/by/4.0/ The Creative Commons Public Domain Dedication waiver (http://creativecommons.org/publicdomain/zero/1.0/) applies to the data made available in this article, unless otherwise stated in a credit line to the data. 
Conclusions: This one sample Mendelian randomization analysis shows genetic evidence for a causal role of lower $25(\mathrm{OH}) \mathrm{D}$ concentrations in promoting of T2D and abnormal DBP in middle-aged and elderly participants from rural China.

Keywords: 25-hydroxyvitamin D, Genetic risk scores, Mendelian randomization, Metabolic syndrome, Type 2 diabetes

\section{Background}

Metabolic syndrome (MS) encompasses a cluster of conditions such as abdominal obesity, hypertension, dyslipidemia, and hyperglycemia [1], that contribute to an increased risk of diabetes, heart disease, and death [2]. MS is a serious burden on public health, and its management is difficult [3]. China and many other Asian countries have recently been experiencing dramatic increases in cases of MS and its components, leading to a high incidence of ensuing problems, especially in middle-aged and elderly Chinese populations [4-7]. During the period from 2014 to 2015, the prevalence of MS, type 2 diabetes (T2D), and hypertension were approximately $18.4,8.5$, and $36.6 \%$, respectively, in the middle-aged Chinese population, and $22.8,15.3$, and $55.7 \%$, respectively, in the elderly Chinese population $[4,6,7]$. The etiology of MS and its components involves a complex interaction of multiple genetic and environmental factors, and its suggested heritability estimates range from 13 to $30 \%[8,9]$.

Vitamin D deficiency is common in European, Indian, South American, and Chinese populations and is particularly notable in middle-aged and elderly Chinese populations $[10,11]$. Vitamin D deficiency is associated with MS [10], hypertension [12], cardiovascular disease [13], glucose homeostasis, and T2D [14], as well as obesity and abdominal obesity [15]. Serum 25hydroxyvitamin D $(25[\mathrm{OH}] \mathrm{D})$, a generally accepted biomarker of circulating vitamin D levels in humans, has been found to be inversely associated with MS and T2D in middle-aged and elderly individuals from China [10, 16]. However, the rationale for low concentrations of vitamin D contributing to MS and its associated diseases remains unclear. Studies on genetic variants that specifically affect $25(\mathrm{OH})$ D concentrations may aid in clarifying the causal association.

Advances in the methodology of large-scale genetic association studies along with international collaboration have identified four single-nucleotide polymorphisms (SNPs) from four genes that influence $25(\mathrm{OH})$ D concentrations $[17,18]$. Genetic variants of synthesis genes $D H C R 7 / N A D$ SYN1 (7-dehydrocholesterol reductase) and CYP2R1 (25hydroxylase) affect the synthesis of $25(\mathrm{OH}) \mathrm{D}$; the transport gene $G C$ (group-specific component) encodes the vitamin D-binding protein, and the catabolism gene CYP24A (24hydroxylase) is involved in the clearance of $25(\mathrm{OH}) \mathrm{D}$ [19].
We calculated genetic risk scores (GRSs) as instrumental variables (IVs) to estimate the causal effects of circulating vitamin D on MS and T2D; Mendelian randomization (MR), which refers to the random allocation of alleles during meiosis, was used [20]. In MR, allocation is expected to be independent of behavioral and environmental factors, thus allowing for the assessment of non-confounded risk associations that are not because of reverse causality [20,21]. MR uses genetic variants as IVs to assess the causal effect of phenotypes, such as vitamin D status, on diseases such as MS, and this is believed to limit unmeasured confounding [21]. However, causal associations between vitamin D and metabolic diseases remain unclear. Previous studies have not provided consistent results [22-28]. It has been reported that every $10 \%$ increase in genetically instrumented $25(\mathrm{OH}) \mathrm{D}$ concentrations is associated with decreased diastolic blood pressure (DBP) and an $8.1 \%$ decrease in the risk of hypertension [25]. A 25-nmol/L higher genetically instrumented $25(\mathrm{OH}) \mathrm{D}$ concentration using two synthesis SNPs was associated with a 14\% lower risk of T2D; conversely, no association was found between genetically instrumented $25(\mathrm{OH})$ D using four vitamin Drelated SNPs and T2D [24]. However, other studies conducted in China have reported no association of genetically determined $25(\mathrm{OH}) \mathrm{D}$ concentrations with MS and its metabolic traits [23] or T2D [26]. Nevertheless, these studies did not specifically target middle-aged and elderly populations. Thus, this study aimed to evaluate the association between serum $25(\mathrm{OH})$ D concentrations and its genetic determinants with MS and its component diseases, such as T2D, in middle-aged and elderly participants from rural eastern China.

\section{Methods}

\section{Participants and study design}

The Nantong Chronic Diseases Study included a cohort of 70,458 participants, aged $18-90$ years who were enrolled from six communities in Nantong, China between 2017 and 2018. A subset of 2393 middle-aged and elderly people (aged above 45 years) was selected for this study. Information on demographics, lifestyle, personal medical history, and family history of chronic diseases was collected by trained interviewers during an inperson interview; participants were asked to provide a fasting blood sample. The study protocol was approved 
by the Institutional Review Boards of Nantong University and the Nantong Centers for Disease Control. All participants provided written informed consent.

The study design is shown in Fig. 1. In this study, associations between $25(\mathrm{OH}) \mathrm{D}$-related genetic variants and $25(\mathrm{OH}) \mathrm{D}$ concentrations $\left(\mathrm{A}\left(\beta_{\mathrm{ZX}}\right)\right)$ and between $25(\mathrm{OH}) \mathrm{D}$-related genetic variants and MS/T2D $\left(\mathrm{C}\left(\beta_{\mathrm{ZY}}\right)\right)$ were assessed, and observational assessments of the association between $25(\mathrm{OH}) \mathrm{D}$ concentrations and MS/ $\mathrm{T} 2 \mathrm{D}\left(\mathrm{B}\left(\beta_{\mathrm{XY}}\right)\right)$ were recorded.

\section{Anthropometric and biochemical measurements}

Anthropometric measurements of weight, height, and waist and hip circumference (WC and $\mathrm{HC}$, respectively) were performed twice according to a standard protocol. If the difference between the first two measurements was greater than $1 \mathrm{~cm}$ for circumference or $1 \mathrm{~kg}$ for weight, a third measurement was taken. The averages of the two closest measurements were then used in the present study. The waist-hip ratio (WHR) and body mass index (BMI) were calculated from these measurements; BMI was calculated as the weight in $\mathrm{kg}$ divided by the square of height in meters.

Serum $25(\mathrm{OH})$ D concentrations were assayed using enzyme linked immunosorbent assay; we defined $25(\mathrm{OH})$ D concentrations $<25 \mathrm{nmol} / \mathrm{L}$ as severe deficiency, 25 to $<50 \mathrm{nmol} / \mathrm{L}$ as deficiency, 50 to $<75 \mathrm{nmol} /$ $\mathrm{L}$ as insufficiency, and $\geq 75 \mathrm{nmol} / \mathrm{L}$ as sufficiency [29]. Levels of fasting blood glucose (FBG) and blood lipids (triglyceride [TG] and high-density lipoprotein cholesterol [HDL-c]) were also measured; insulin levels were measured using a chemiluminescent immunoassay. The homeostasis model assessment of insulin resistance (HOMR-IR) was calculated based on the following formula: $\mathrm{HOMR}-\mathrm{IR}=(\mathrm{FBG}(\mathrm{mmol} / \mathrm{L}) \times$ insulin $(\mu \mathrm{IU} / \mathrm{mL})) /$ 22.5. Blood pressure, comprising of both systolic blood pressure (SBP) and diastolic blood pressure (DBP), was assessed twice in a time interval of more than $3 \mathrm{~min}$. If the difference between the first two measurements was larger than $10 \mathrm{mmHg}$, a third measurement was performed; the averages of the two closest measurements were used in this study. Other demographic data, including those related to education, income, lifestyle factors (i.e., physical activity, smoking and alcohol consumption status), personal medical history, family history of chronic diseases, and use of vitamin D and calcium supplements, were collected using a standardized questionnaire.

\section{Diagnostic criteria for MS and T2D}

In this study, the definition of MS was based on the joint interim statement of the International Diabetes Federation criteria [30], adopting the Asian criteria for WC. It mandated the inclusion of $\geq 3$ of the following metabolic abnormalities: central obesity: WC $\geq 85 \mathrm{~cm}$ for Chinese men and $\geq 80 \mathrm{~cm}$ for Chinese women; abnormal fasting blood serum TG levels $\geq 1.7 \mathrm{mmol} / \mathrm{L}$ or taking TGlowering medication; abnormal fasting serum HDL-c levels $<1.3 \mathrm{mmol} / \mathrm{L}$ for Chinese women and $<1.0 \mathrm{mmol} /$ $\mathrm{L}$ for Chinese men or receiving treatment for increasing HDL-c levels; abnormal blood pressure with $\mathrm{SBP} \geq 130$ $\mathrm{mmHg}, \mathrm{DBP} \geq 85 \mathrm{mmHg}$, or receiving antihypertensive

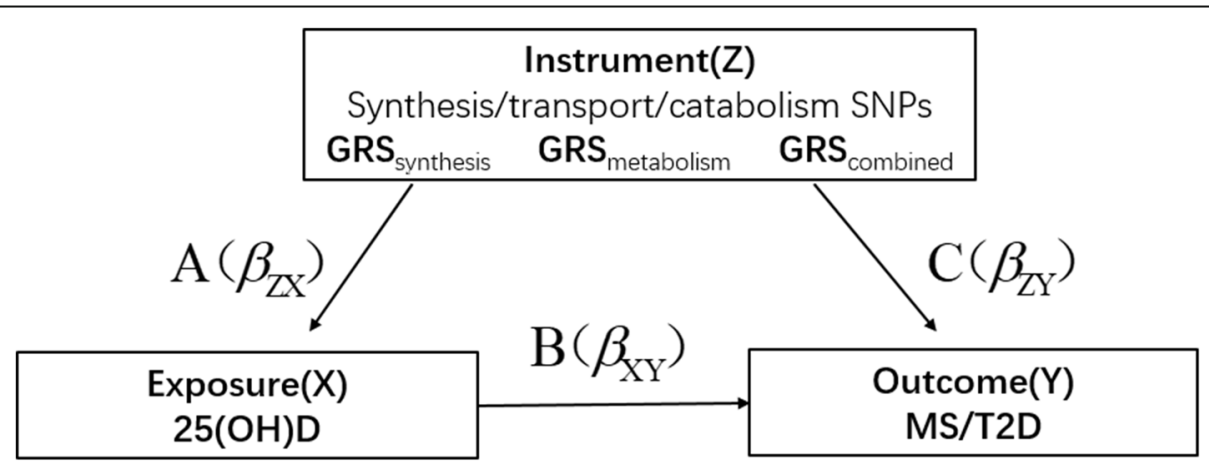

$$
\begin{gathered}
\text { Wald ratio } \beta_{\mathrm{IV}}=\beta_{\mathrm{ZY}} / \beta_{\mathrm{ZX}} \\
\mathrm{SE}_{\mathrm{IV}}=\operatorname{abs}\left(\beta_{\mathrm{IV}}\right) \sqrt{\left(\frac{S E_{\text {SNP/GRS_exposure }}}{\beta_{\text {SNP/GRS_exposure }}}\right)^{2}+\left(\frac{S E_{\text {SNP/GRS_outcome }}}{\beta_{S N P / G R S \_ \text {outcome }}}\right)^{2}}
\end{gathered}
$$

Fig. 1 Study design and tested associations. GRS, genetic risk score; $25(\mathrm{OH}) \mathrm{D}, 25$-hydroxyvitamin $\mathrm{D}$; IV, instrumental variable 
medication; and abnormal fasting serum glucose (prediabetes) level $\geq 5.6 \mathrm{mmol} / \mathrm{L}$ or receiving anti-diabetic medication.

T2D was defined based on FBG levels $\geq 7.0 \mathrm{mmol} / \mathrm{L}$ and/or 2-h oral glucose tolerance test results $\geq 11.1$ $\mathrm{mmol} / \mathrm{L}$; treatment with anti-diabetic medication and/or previous diagnosis of diabetes by a physician were also used to define the presence of T2D [31].

\section{SNP selection and genotyping}

For the four vitamin D-related SNPs, two synthesis SNPs (DHCR7/NADSYN1-rs12785878 and CYP2R1rs10741657), one transport SNP (GC-rs2282679), and one catabolism SNP (CYP24A1-rs6013897) were selected; this is similar to the method of a recent study in an Asian cohort [32]. These SNPs were significantly associated with plasma $25(\mathrm{OH}) \mathrm{D}$ concentrations in a previous genome-wide association study (GWAS) [18] and were also used in Mendelian analyses in studies on Chinese populations $[23,24]$. The genotyping concordance was $>99.9 \%$, and the genotype success rate was 99.9\% for each SNP. All four SNPs were on the HardyWeinberg equilibrium $(P>0.05)$, and the frequency of alleles was $>0.05$.

Genotyping was performed using the iPLEX ${ }^{\mathrm{ma}}$ Sequenom MassARRAY ${ }^{\circ}$ platform. Polymerase chain reaction (PCR) and extension primers were designed using MassARRAY Assay Design 3.0 software (Sequenom, Inc). PCR and extension reactions were performed according to the manufacturer's instructions, and extension product sizes were determined using mass spectrometry with the Sequenom iPLEX system. On each 96-well plate, two negative controls (water), two blinded duplicates, and two samples were included.

\section{GRSs}

We assumed an additive genetic model for SNPs with scores of 0,1 , or 2 for genotypes containing 0,1 , or 2 alleles, respectively, based on the relationship between the SNPs and circulating vitamin D levels. GRSs were the sum of scores for each SNP multiplied by the $\beta$ value from a previous study [32]. We calculated the $\mathrm{GRS}_{\text {synth- }}$ esis for two synthesis SNPs, (DHCR7-rs12785878 +

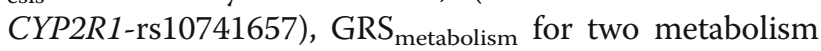
SNPs (GC-rs2282679 + CYP24A1- rs6013897), and GRS $_{\text {combined }}$ for all four SNPs.

\section{Statistical analyses}

Normally distributed continuous variables are presented as means \pm standard deviation (SD) and compared using ANOVA. Non-normally distributed continuous variables are expressed as medians (interquartile range [IQR]) and analyzed using the Wilcoxon rank sum test. Categorical variables are expressed as percentages; the Pearson's chi- square test was used for comparison between MS/T2D cases and MS/T2D non-cases. Furthermore, clinical characteristics (such as glucose, TG, hypertension, among others) were compared between the quintiles of $25(\mathrm{OH})$ D concentration groups using ANOVA for continuous variables with normal distribution, the KruskalWallis test for continuous variables with non-normal distribution, and Pearson's chi-square test for categorical variables.

First, linear regression was used to determine the association of each SNP with $25(\mathrm{OH})$ D concentrations $\left(\mathrm{A}\left(\beta_{\mathrm{ZX}}\right)\right)$, assuming linear effects of each vitamin-D related SNP per additional allele on 25(OH)D. The CraggDonald F-statistic $\left[F=\frac{\left(R^{2} *(\mathrm{n}-2)\right)}{\left(1-R^{2}\right)}\right]$ was used to estimate the strength of the association, and $F$ values $>10$ were regarded as useful for MR analysis [33]. The association of each SNP with MS and T2D was then determined using logistic regression $\left(C\left(\beta_{\mathrm{ZY}}\right)\right)$. Genetically determined $\mathrm{A}\left(\beta_{\mathrm{ZX}}\right)$ and $\mathrm{C}\left(\beta_{\mathrm{ZY}}\right)$ were calculated using the Wald ratio estimator $\left(\beta_{\mathrm{IV}}=\beta_{\mathrm{ZY}} / \beta_{\mathrm{ZX}}\right)$ [34]. The Wald ratios of the four SNPs were meta-analyzed in an inversevariance weighted meta-analysis to compute the MR estimate based on the fixed effect model $\hat{\beta}_{\mathrm{IVW}}=\left(\sum_{j=1}^{4} \omega_{j}\right.$ $\left.\beta_{I V_{j}}\right) / \sum_{j=1}^{4} \omega_{j}, \omega_{j}=1 / \operatorname{var}\left(\beta_{I V_{j}}\right), j=1, \ldots \ldots, 4$. Furthermore, the effects of pleiotropy for the four SNPs were analyzed using MR-Egger regression, in which the $p$ value of intercept gives a valid test of directional pleiotropy [35].

To explore the observational associations $\left(\beta_{\mathrm{XY}}\right)$ of $25(\mathrm{OH}) \mathrm{D}$ with MS/T2D, logistic regression analysis was used to estimate the odds ratios (ORs) and 95\% confidence intervals (CIs). Effect estimates were presented per $10-\mathrm{nmol} / \mathrm{L}$ or per $25-\mathrm{nmol} / \mathrm{L}$ decrease in $25(\mathrm{OH}) \mathrm{D}$ concentrations or quintiles $25(\mathrm{OH}) \mathrm{D}$ adjusted for confounders, that differed between MS/T2D cases and nonMS/T2D cases.

The association of $\mathrm{GRS}_{\text {synthesis, }} \mathrm{GRS}_{\text {metabolism, and }}$ $\mathrm{GRS}_{\text {combined }}$ with $25(\mathrm{OH})$ D $\left(\beta_{G R S-V D}\right)$ was estimated using linear regression analysis. $\mathrm{GRS}_{\text {combined }}$, $\mathrm{GRS}_{\text {synthesis, }}$

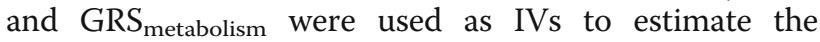
causal effect of 25(OH) D on T2D and MS and its components adjusted for confounders. IV estimates of genetically determined OR were obtained with the Wald-type estimator $O R_{I V(V D-\text { outcome })}=\exp \left(\ln \left(O R_{G R S-\text { outcome }}\right) /\right.$ $\left.\beta_{G R S-V D}\right)$. Effect estimates of GRSs have been presented per unit higher in GRS; $O R_{I V(V D-\text { outcome })}$ denoted a genetically determined of per $25-\mathrm{nmol} / \mathrm{L}$ decrease in $25(\mathrm{OH})$ D concentrations.

Another method for calculating IV employs a twostage regression estimator to calculate causal ORs per 
$25-\mathrm{nmol} / \mathrm{L}$ increase in $25(\mathrm{OH}) \mathrm{D}$ concentrations to explain the sensitivity analyses [36]. In the first stage, a linear regression of $25(\mathrm{OH}) \mathrm{D}$ on GRSs was used to generate $25(\mathrm{OH}) \mathrm{D}$-fitted values. In the second stage, the predicted $25(\mathrm{OH}) \mathrm{D}$ values from the first stage were used for logistic regression with T2D and MS and its components as the dependent variable.

All analyses were performed using SAS (version 9.3; SAS Institute, Cary, NC), and $P<0.05$ was considered statistically significant; all results were based on twosided probability.

\section{Results}

The prevalence of MS and T2D in the 2393 participants were 31.17 and $15.09 \%$, respectively. Table 1 presents the differences among select demographic characteristics, anthropometric measurements, and lifestyle factors between MS/T2D cases and MS/T2D non-cases. Both MS and T2D cases were older, had higher weight, greater WC, higher BMI, and greater WHR than nonMS/T2D cases. The composition ratio of MS/T2D and non-MS/T2D cases was not balanced among the groups based on different income, alcohol consumption status, physical activity, or familial history of MS/T2D. Moreover, the composition ratio of MS and non-MS cases was not balanced with regard to smoking status.

We found significant differences in demographic and clinical characteristics among the five quintile groups of serum $25(\mathrm{OH}) \mathrm{D}$ concentrations (Table 2). The median FBG $(5.49 \mathrm{mmol} / \mathrm{L})$, insulin $(73.24 \mathrm{pmol} / \mathrm{L})$, HOMA-IR (1.41), and TG $(0.97 \mathrm{mmol} / \mathrm{L})$ values and the mean WC $(75.26 \mathrm{~cm})$ were the lowest, while the median HDL-c $(1.35 \mathrm{mmol} / \mathrm{L})$ value was the highest in the highest quintile (Q5) of serum 25(OH)D.

Figure 2 shows the scatterplot of the associations of per allele effects of the four SNPs for $25(\mathrm{OH})$ D concentrations with the risk of MS/T2D, by their effects on $25(\mathrm{OH}) \mathrm{D}$ according to the study population. All four SNPs were associated with $25(\mathrm{OH})$ D concentrations $(P<0.05)$. Concentrations of $25(\mathrm{OH}) \mathrm{D}$ per allele (increasing $25(\mathrm{OH}) \mathrm{D}$ concentrations) were higher by 1.10 $\mathrm{nmol} / \mathrm{L} \quad(95 \% \quad$ CI: $\quad 0.74-1.46 \mathrm{nmol} / \mathrm{L})$ for $\quad$ CY2R1 rs10741657, $2.14 \mathrm{nmol} / \mathrm{L}(1.82-2.46 \mathrm{nmol} / \mathrm{L})$ for DHCR7 $\mathrm{rs} 12785878, \quad 2.94 \mathrm{nmol} / \mathrm{L} \quad(2.56-3.32 \mathrm{nmol} / \mathrm{L})$ for GC rs2282679, and $0.74 \mathrm{nmol} / \mathrm{L} \quad(0.32-1.16 \mathrm{nmol} / \mathrm{L})$ for CYP24A1 rs6013897. The F-statistic ranged from 17.4 to 67.8 across each SNP, indicating an adequately strong association for MR analysis. However, none of the 25(OH)D-related SNPs were significantly associated with MS/T2D. The four SNPs accounted for the variation in exposure considerably more than the outcomes. The absolutes of the Wald ratios $(95 \% \mathrm{CI})$ ranged from 0.02 ($0.11-0.14)$ to $0.28(0.01-0.86)$, indicating a causal effect of exposure $(25(\mathrm{OH}) \mathrm{D})$ on outcomes (MS/T2D).
Moreover, Fig. 2 shows some evidence of pleiotropy for transport and catabolism SNPs, the $p$-value for the MREgger intercept was 0.043 and 0.052 for the four SNPs in T2D and MS, respectively, while the intercepts of two synthesis SNPs are almost to zero, suggested possible pleiotropy for metabolism SNPs.

Table 3 presents the association of serum $25(\mathrm{OH}) \mathrm{D}$ concentration with MS and T2D in the study population. Significant associations were found between serum 25(OH) D and both MS and T2D. Compared to the highest quintile of serum $25(\mathrm{OH}) \mathrm{D}(\geq 57.5 \mathrm{nmol} / \mathrm{L})$, individuals with the third quintile of serum $25(\mathrm{OH})$ D $(36.8-45.9 \mathrm{nmol} / \mathrm{L})$ had an OR $(95 \% \mathrm{CI})$ of MS of 1.29 (1.03-1.75) and of T2D of 1.33 (1.05-1.67), individuals with the fourth quintile of $25(\mathrm{OH}) \mathrm{D}(28.5-36.7 \mathrm{nmol} / \mathrm{L})$ had an OR (95\% CI) of MS of 1.47 (1.17-1.81) and of T2D of 1.50 (1.17-1.82), and individuals with the lowest quintile of serum $25(\mathrm{OH}) \mathrm{D}(<28.4 \mathrm{nmol} / \mathrm{L})$ had an OR (95\% CI) of MS of 1.55 (1.24-1.89) and of T2D of 1.53 (1.21-1.87), respectively, among middle-aged and elderly Chinese participants. Similarly, compared to the sufficiency category of vitamin $\mathrm{D}(\geq 75 \mathrm{nmol} / \mathrm{L})$, there was an increased prevalence of MS and T2D in the insufficiency category of vitamin D $(25(\mathrm{OH}) \mathrm{D}: 50$ to $<75 \mathrm{nmol} / \mathrm{L})$, with ORs (95\% CI) of $1.30(1.06-1.61)$ and $1.32(1.08-$ 1.64), respectively; these values were 1.50 (1.24-1.79) and $1.47(1.12-1.80)$, respectively, in the deficiency category of vitamin D (25(OH)D: 25 to $<50 \mathrm{nmol} / \mathrm{L})$ and $1.52(1.29-1.85)$ and $1.54(1.27-1.85)$, respectively, in the severe deficiency category of vitamin D $(25(\mathrm{OH}) \mathrm{D}:<$ $25 \mathrm{nmol} / \mathrm{L}$ ). Overall, every $25-\mathrm{nmol} / \mathrm{L}$ decrease in serum $25(\mathrm{OH}) \mathrm{D}$ concentrations was associated with an increased risk of MS and T2D (OR [95\% CI]: 1.23 [1.061.52 ] and 1.14 [1.05-1.33], respectively).

Table 4 shows the causal coefficients from the MR analysis for the association of MS, T2D, and abnormal SBP and DBP with vitamin D-determined GRSs. Regarding $\mathrm{OR}_{\mathrm{ZY}}$, one unit higher $\mathrm{GRS}_{\text {synthesis }}$ was associated with an increased risk of T2D and abnormal DBP (OR [95\%CI]: 1.07 [1.01-1.42] and 1.16 [1.02-1.65], respectively). No significant associations were observed among GRS $_{\text {metabolism, }}$ GRS $_{\text {combined, }}$ and T2D and MS and its components. Furthermore, no significant association was found between serum 25(OH)D-determining genetic variants and MS risk. However, MR analysis found that a per $25-\mathrm{nmol} / \mathrm{L}$ decrease in genetically instrumented serum $25(\mathrm{OH})$ D concentrations using two synthesis SNPs (DHCR7-rs12785878 + CYP2R1-rs10741657) was associated with an increasing risk of T2D (OR [95\%CI]: 1.10 [1.02-1.45]) and abnormal DBP (1.14 [1.03-1.43]). Moreover, we did not find any association between genetically instrumented serum $25(\mathrm{OH})$ D concentration of two metabolism and all four SNPs with T2D. Null results were obtained between genetically instrumented 
Table 1 Characteristics of study participants: MS/T2D cases and non-cases ( $n=2393)$

\begin{tabular}{|c|c|c|c|c|c|c|}
\hline & $\begin{array}{l}\text { MS cases } \\
(n=746)\end{array}$ & MS non-cases $(n=1647)$ & $\mathbf{P}$ & T2D cases $(n=361)$ & T2D non-cases $(n=2032)$ & $P$ \\
\hline Age $($ year, $\bar{x} \pm S D)$ & $61.24 \pm 6.41$ & $56.68 \pm 6.19$ & $<0.001^{*}$ & $60.30 \pm 6.54$ & $57.71 \pm 6.41$ & $<0.001^{*}$ \\
\hline Weight $(\mathrm{kg}, \bar{x} \pm S D)^{1}$ & $64.35 \pm 18.41$ & $58.85 \pm 18.20$ & $<0.001^{*}$ & $66.26 \pm 18.92$ & $54.87 \pm 18.63$ & $<0.001^{*}$ \\
\hline$W C(\mathrm{~cm}, \bar{x} \pm S D)^{1}$ & $87.76 \pm 10.32$ & $78.75 \pm 10.16$ & $<0.001^{*}$ & $89.86 \pm 11.26$ & $76.10 \pm 10.97$ & $<0.001^{*}$ \\
\hline BMI $\left(\mathrm{kg} / \mathrm{m}^{2}, \bar{x} \pm S D\right)^{1}$ & $26.66 \pm 4.02$ & $22.47 \pm 3.87$ & $<0.001^{*}$ & $27.62 \pm 4.12$ & $21.38 \pm 4.06$ & $<0.001^{*}$ \\
\hline $\mathrm{WHR}(\bar{x} \pm S D)^{1}$ & $0.94 \pm 0.14$ & $0.88 \pm 0.12$ & $<0.001^{*}$ & $0.95 \pm 0.13$ & $0.87 \pm 0.11$ & $<0.001^{*}$ \\
\hline Education (\%) ${ }^{1}$ & & & 0.259 & & & 0.644 \\
\hline Illiterate & 0.00 & 100.00 & & 0.00 & 100.00 & \\
\hline Primary school & 28.48 & 71.52 & & 12.06 & 87.94 & \\
\hline Middle school & 30.23 & 69.77 & & 14.86 & 85.14 & \\
\hline High school & 32.26 & 67.74 & & 15.25 & 84.75 & \\
\hline Colleges and above & 31.86 & 68.14 & & 15.99 & 84.01 & \\
\hline \multicolumn{2}{|c|}{ Income (yuan/month, \%) ${ }^{1}$} & & $<0.001^{*}$ & & & $0.040^{*}$ \\
\hline$<2000$ & 26.53 & 73.47 & & 13.01 & 86.99 & \\
\hline $2000-$ & 30.49 & 69.51 & & 14.33 & 85.67 & \\
\hline $3500-$ & 31.32 & 68.68 & & 15.64 & 84.36 & \\
\hline$\geq 3500$ & 43.61 & 56.39 & & 21.10 & 78.90 & \\
\hline \multicolumn{2}{|l|}{ Smoking status (\%) ${ }^{1}$} & & $<0.001^{*}$ & & & 0.488 \\
\hline Never-smokers & 26.90 & 73.10 & & 14.72 & 85.28 & \\
\hline Ever smokers & 32.69 & 67.31 & & 13.70 & 86.30 & \\
\hline Current smokers & 38.89 & 61.11 & & 16.33 & 83.67 & \\
\hline \multicolumn{2}{|l|}{ Drinking status (\%) ${ }^{1}$} & & $<0.001^{*}$ & & & $0.003^{*}$ \\
\hline Never-drinkers & 28.87 & 71.13 & & 14.35 & 85.65 & \\
\hline Ever drinkers & 47.36 & 52.64 & & 27.68 & 72.32 & \\
\hline Current drinkers & 33.18 & 66.82 & & 14.98 & 85.02 & \\
\hline \multicolumn{2}{|l|}{ Physical activity (\%) ${ }^{1}$} & & $<0.001^{*}$ & & & $0.042^{*}$ \\
\hline No & 33.00 & 67.00 & & 15.89 & 84.11 & \\
\hline Yes & 24.86 & 75.14 & & 12.31 & 87.69 & \\
\hline \multicolumn{2}{|l|}{ CHD (\%) } & & 0.352 & & & 0.729 \\
\hline No & 31.01 & 68.99 & & 15.03 & 84.97 & \\
\hline Yes & 37.42 & 62.58 & & 17.43 & 82.57 & \\
\hline \multicolumn{2}{|c|}{ Familial history of MS/T2D (\%) } & & $<0.001^{*}$ & & & $0.040^{*}$ \\
\hline No & 28.29 & 71.71 & & 14.40 & 85.60 & \\
\hline Yes & 44.55 & 55.45 & & 18.25 & 81.75 & \\
\hline \multicolumn{2}{|l|}{ Vitamin D supplement (\%) } & & 0.830 & & & 0.849 \\
\hline No & 31.22 & 68.78 & & 15.09 & 84.91 & \\
\hline Yes & 29.64 & 70.36 & & 14.78 & 85.22 & \\
\hline \multicolumn{2}{|l|}{ Calcium supplement (\%) } & & 0.585 & & & 0.739 \\
\hline No & 31.27 & 68.73 & & 15.04 & 84.96 & \\
\hline Yes & 28.88 & 71.12 & & 16.15 & 83.85 & \\
\hline
\end{tabular}

Abbreviations: WC waist circumference, BMI body mass index, WHR waist-hip ratio, CHD coronary heart disease, ${ }^{1}:$ adjusted for age at interview. ${ }^{*} \mathrm{P}<0.05$. ANOVA was performed on age at interview, weight, WC, BMI and WHR; the $x^{2}$ test was performed on the other variables to compare differences between case and non-case groups 
Table 2 Comparison of clinical characteristics among different groups based on serum 25(OH) D concentration

\begin{tabular}{|c|c|c|c|c|c|c|}
\hline & \multicolumn{5}{|c|}{ Vitamin D Concentration (nmol/L) } & \multirow[t]{2}{*}{$\mathbf{P}$} \\
\hline & $\mathrm{Q1}(<28.4)$ & Q2(28.5-36.7) & Q3(36.8-45.9) & Q4(46.0-57.4) & $\mathrm{Q} 5(\geq 57.5)$ & \\
\hline $\mathrm{n}$ & 476 & 483 & 495 & 468 & 471 & \\
\hline Age (year, $\bar{x} \pm S D)$ & $59.81 \pm 7.04$ & $59.58 \pm 7.02$ & $59.97 \pm 6.94$ & $59.44 \pm 7.18$ & $58.82 \pm 7.07$ & 0.070 \\
\hline Female, n (\%) & $291(61.13)$ & 285(59.00) & $301(60.81)$ & $282(60.26)$ & $279(59.24)$ & 0.950 \\
\hline FBG (mmol/L, M (IQU)) & $5.80(1.09)$ & $5.69(1.19)$ & $5.68(1.19)$ & $5.60(1.08)$ & $5.49(0.90)$ & $0.002^{*}$ \\
\hline Insulin (pmol/L, M (IQU)) & $88.24(61.70)$ & $87.96(60.38)$ & $83.15(52.22)$ & $80.78(47.42)$ & $73.24(43.8)$ & $<0.001^{*}$ \\
\hline HOMA-IR & $1.69(1.12)$ & $1.68(1.09)$ & $1.60(0.94)$ & $1.50(0.88)$ & $1.41(0.82)$ & $<0.001^{*}$ \\
\hline TG (mmol/L, M (IQU)) & $1.24(0.97)$ & $1.23(0.98)$ & $1.20(0.98)$ & $1.09(0.88)$ & $0.97(0.74)$ & $<0.001^{*}$ \\
\hline HDL-c (mmol/L, M (IQU)) & $1.21(0.99)$ & $1.24(0.98)$ & $1.24(0.98)$ & $1.28(1.00)$ & 1.35(0.96) & $<0.001^{*}$ \\
\hline $\mathrm{BMI}\left(\mathrm{Kg} / \mathrm{m}^{2}, \bar{x} \pm S D\right)$ & $25.15 \pm 3.98$ & $24.92 \pm 4.01$ & $25.18 \pm 3.87$ & $24.64 \pm 3.77$ & $24.44 \pm 4.05$ & 0.064 \\
\hline$W C(\mathrm{~cm}, \bar{x} \pm S D)$ & $86.33 \pm 11.09$ & $85.83 \pm 10.52$ & $84.86 \pm 10.75$ & $81.45 \pm 11.04$ & $75.26 \pm 10.43$ & $<0.001^{*}$ \\
\hline Hypertension, n (\%) & $267(56.09)$ & $271(56.11)$ & 273(55.15) & $240(51.28)$ & $230(48.83)$ & 0.085 \\
\hline Familial history of diabetes, $\mathrm{n}(\%)$ & $69(14.50)$ & $73(15.11)$ & $72(14.55)$ & $60(12.82)$ & $59(12.53)$ & 0.717 \\
\hline Familial history of CHD, n (\%) & $120(25.21)$ & $119(24.64)$ & $122(24.65)$ & $117(25.00)$ & $102(21.66)$ & 0.701 \\
\hline
\end{tabular}

${ }^{*}: \mathrm{P}<0.05$. Abbreviations BMI body mass index, CHD coronary heart disease, FBG fasting blood glucose, HDL-c high-density lipoprotein cholesterol, $H O M A-I R$ homeostasis model assessment of insulin resistance, $T G$ triglyceride, WC waist circumference, $\mathrm{x}^{-} \pm \mathrm{SD}$ : mean \pm standard deviation; $M$ (IQU): median (interquartile range)

serum $25(\mathrm{OH})$ D concentrations using any single SNP and MS or T2D in the middle-aged and elderly participants from eastern rural China (data not shown).

The results of the sensitivity analyses of another twostage regression estimator for calculating the $\mathrm{OR}_{\mathrm{IV}}$ per $25-\mathrm{nmol} / \mathrm{L}$ increase in $25(\mathrm{OH}) \mathrm{D}$ concentrations has been shown in Additional file 1. The results were considerably similar to those obtained using the Wald-type estimator. Significant associations were observed between $25(\mathrm{OH}) \mathrm{D}$ genetically determined by $\mathrm{GRS}_{\text {synthesis }}$ and T2D and abnormal DBP (OR [95\%CI]: 1.08[1.031.38] and 1.09[1.02-1.37] per 25-nmol/L 25(OH) D decrease).

\section{Discussion}

Vitamin D levels are known to influence the development of MS and component diseases, but the causality or direction of the association has been uncertain. This study showed that genetically determined $25(\mathrm{OH}) \mathrm{D}$ levels are causally associated with T2D and abnormal DBP in middle-aged and elderly rural participants from east rural China.

Many epidemiological studies have found inverse associations between serum 25(OH) D levels and MS and its component diseases [10, 37, 38]. Previous studies reported a positive correlation between vitamin $\mathrm{D}$ and HDL-c levels, but an inverse association with TG, SBP and DBP [10], T2D [38], BMI, and WC [39]. This study found that a higher serum $25(\mathrm{OH}) \mathrm{D}$ concentration was significantly associated with lower glucose concentrations, insulin levels, HOMA-IR, WC and higher HDL-C levels. Fully adjusted ORs (95\% CI) for an increased risk of MS and T2D were 1.55 (1.24-1.89) and 1.53 (1.211.87 ) in the lowest quintile of serum $25(\mathrm{OH}) \mathrm{D}$ concentrations compared with the highest quintile of serum concentrations. This finding is consistent with the findings of the study by Afzal et al. [40] where the multivariable adjusted hazard ratio of T2D was 1.35 (1.09-1.66) for the lowest quartile compared with the highest quartile of serum $25(\mathrm{OH}) \mathrm{D}$. The finding is also consistent with the findings of Bea et al. [37], in that serum $25(\mathrm{OH}) \mathrm{D}$ in the highest quartile decreased the risk for MS (OR $=0.52$ [0.36-0.75]) compared with the lowest quartile of $25(\mathrm{OH}) \mathrm{D}$. However, a number of randomized controlled trials have shown no association between vitamin D levels and the incidence of MS and its component diseases, including T2D in elderly people [41-43]. Furthermore, a cohort study reported that after a year of vitamin D supplementation, people whose serum $25(\mathrm{OH}) \mathrm{D}$ concentrations improved to $<25 \mathrm{nmol} / \mathrm{L}, 25$ to $<50 \mathrm{nmol} / \mathrm{L}, 50$ to $<75 \mathrm{nmol} / \mathrm{L}$, and $\geq 75 \mathrm{nmol} / \mathrm{L}$ had a 0.76-, 0.64-, 0.59-, 0.56-fold risk, respectively, for MS at follow-up [44].

MR studies have provided no evidence to suggest that genetically increased serum $25(\mathrm{OH})$ D concentrations are associated with a lower risk of MS, T2D, or hypertension $[23,27,45]$. The current study did not identify any association of genetically determined vitamin D concentrations, associated SNPs, and GRSs with the risk of MS; however, it did show that a genetically instrumented 25-nmol/L decrease in serum $25(\mathrm{OH}) \mathrm{D}$ concentrations using two synthesis SNPs was associated with a $10 \%$ higher risk of T2D in these middle-aged and elderly participants from eastern rural China. The findings are 

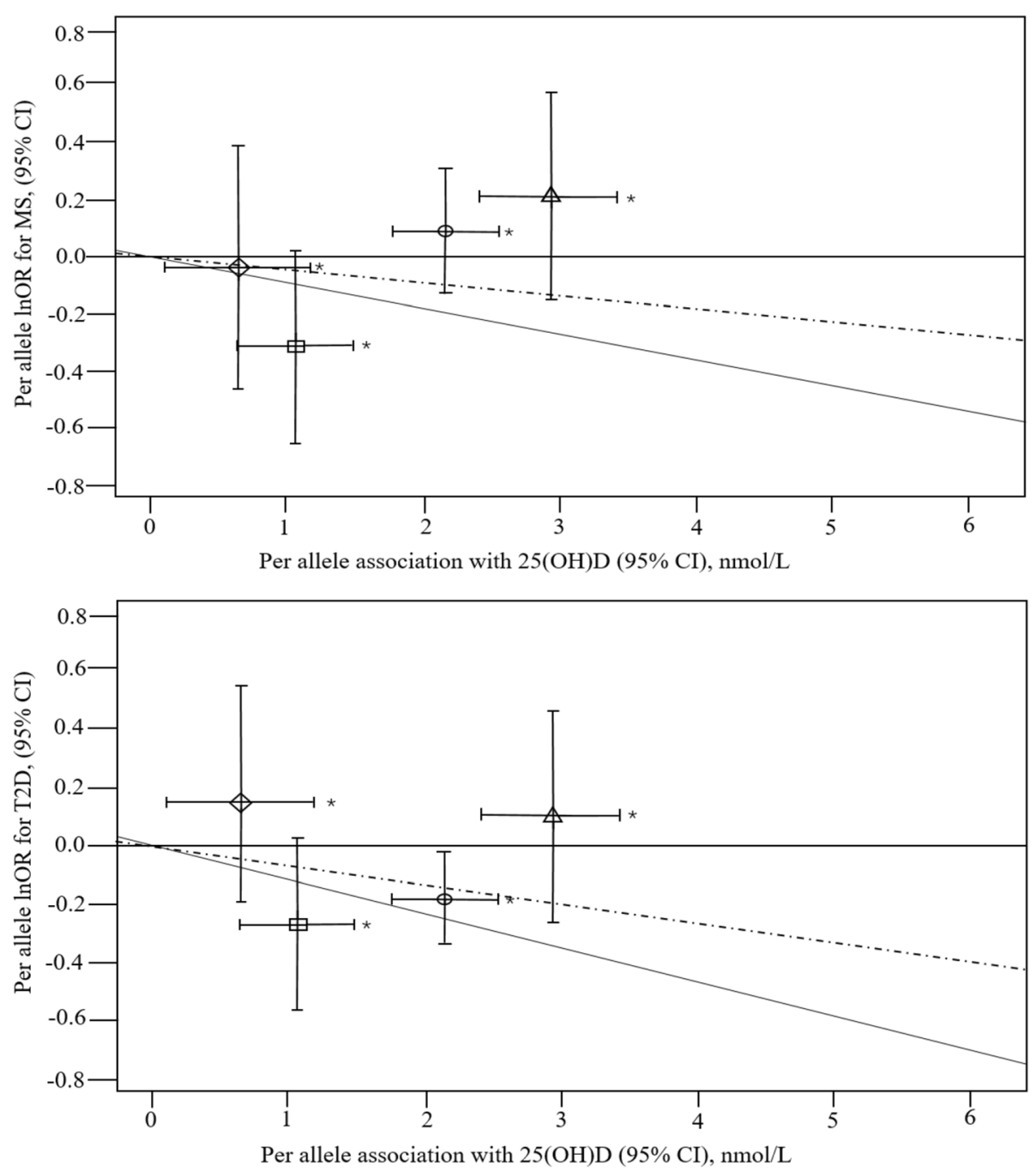

Fig. 2 Scatterplot of associations of per allele effects of the four SNPs with risk of MS/T2D. This association was evaluated for 25(OH) D concentrations in our population based on the effect of the SNPs on 25(OH) D concentration (Square: CYP2R1 - rs 10741657; Circle: DHCR7 rs12785878; Triangle: GC/DBP - rs2282679; Diamond: CYP24A1 - rs6013897). . : P< 0.05. Dashed line: The slope from an inverse-variance weighted linear regression of per allele InOR for MS/T2D for all four SNPs on $25(\mathrm{OH})$ D concentrations, with the line forced through the origin. Fulled line: The slope from an inverse-variance weighted linear regression of per allele InOR for MS/T2D for two synthesis SNPs on 25(OH) D concentrations, with the line forced through the origin

consistent with those from the study by Lu et al. who found a $9 \%$ higher risk of diabetes in Chinese participants and a $14 \%$ higher risk of diabetes from a metaanalysis [24]. Furthermore, a study by Yuan et al. revealed that genetic variants associated with low plasma concentrations were associated with T2D $(P=0.0290)$ [28]. A previous study reported a modest association between the genetic scores of two SNPs of plasma 25(OH) D concentrations and hypertension $(P=0.0003)$ [25]; however, another investigation found no effect on blood pressure in a Chinese population [24]. The present study found that genetically instrumented $25-\mathrm{nmol} / \mathrm{L}$ decreases in serum $25(\mathrm{OH}) \mathrm{D}$ concentrations using two synthesis SNPs was associated with a $14 \%$ higher risk of abnormal DBP in these middle-aged and elderly participants from eastern rural China. It is known that the vitamin D synthesis genes DHCR7/NADSYN1 and CYP2R1, transport gene $G C$, and catabolism gene $C Y P 24 A 1$ contribute to variability in circulating biomarkers of vitamin D levels $[46,47]$. Interestingly, GRSs combined with two metabolism SNPs or four SNPs in these four vitamin Dassociated genes demonstrated no association with T2D and SBP/DBP. However, several studies have reported that both transport and catabolism SNPs show pleiotropy; this includes cases where the MR-Egger regression was used for meta-analysis [24, 47, 48]. Analysis of the association of transport and catabolism SNPs with MS/T2D also shows modest statistically significant 
Table 3 Association of T2D and MS with serum $25(\mathrm{OH}) \mathrm{D}$ concentration

\begin{tabular}{|c|c|c|c|c|c|c|}
\hline & $\begin{array}{l}\text { MS cases } \\
\text { n (\%) }\end{array}$ & $\mathrm{OR}_{\mathrm{XY}}(95 \% \mathrm{Cl})^{1}$ & $\mathbf{P}$ & $\begin{array}{l}\text { T2D cases } \\
\mathrm{n}(\%)\end{array}$ & $\mathrm{OR}_{\mathrm{XY}}(95 \% \mathrm{Cl})^{2}$ & $\mathbf{P}$ \\
\hline Every decreasing $10 \mathrm{nmol} / \mathrm{L} 25(\mathrm{OH}) \mathrm{D}$ & $746(31.17)$ & $1.10(1.02-1.23)$ & $0.027^{*}$ & $361(15.09)$ & $1.07(1.01-1.21)$ & $0.018^{*}$ \\
\hline $\operatorname{Adj}-R^{2}$ & & 0.732 & & & 0.756 & \\
\hline Every decreasing $25 \mathrm{nmol} / \mathrm{L} 25(\mathrm{OH}) \mathrm{D}$ & & $1.23(1.06-1.52)$ & $0.002^{*}$ & & $1.14(1.05-1.33)$ & $0.001^{*}$ \\
\hline Adj-R ${ }^{2}$ & & 0.789 & & & 0.764 & \\
\hline \multicolumn{7}{|l|}{ Quintiles of 25(OH) D (nmol/L) } \\
\hline $\mathrm{Q} 1(\geq 57.5)$ & 135(26.68) & 1.00 & & $53(11.08)$ & 1.00 & \\
\hline Q2(46.0-57.4) & $129(28.48)$ & $1.09(1.01-1.45)$ & $0.025^{*}$ & $64(13.77)$ & $1.12(1.03-1.59)$ & $0.004^{*}$ \\
\hline Q3((36.8-45.9) & 161(31.69) & $1.29(1.03-1.75)$ & $<0.001^{*}$ & $75(15.14)$ & $1.33(1.05-1.67)$ & $<0.001^{*}$ \\
\hline Q4(28.5-36.7) & $167(34.08)$ & $1.47(1.17-1.81)$ & $<0.001^{*}$ & $82(17.13)$ & $1.50(1.17-1.82)$ & $<0.001^{*}$ \\
\hline $\mathrm{Q} 5(<28.4)$ & 154(35.32) & $1.55(1.24-1.89)$ & $<0.001^{*}$ & $87(18.29)$ & $1.53(1.21-1.87)$ & $<0.001^{*}$ \\
\hline Adj- $R^{2}$ & & 0.784 & & & 0.753 & \\
\hline \multicolumn{7}{|l|}{ Clinical categories of $25(\mathrm{OH}) \mathrm{D}(\mathrm{nmol} / \mathrm{L})$} \\
\hline$\geq 75$ & $21(26.12)$ & 1.00 & & $10(12.44)$ & 1.00 & \\
\hline $50-75$ & 196(27.90) & $1.30(1.06-1.61)$ & $0.008^{*}$ & $92(13.08)$ & $1.32(1.08-1.64)$ & $0.001^{*}$ \\
\hline $25-50$ & 390(31.90) & $1.50(1.24-1.79)$ & $<0.001^{*}$ & 188(15.41) & $1.47(1.12-1.80)$ & $<0.001^{*}$ \\
\hline$<25$ & 139(35.91) & $1.52(1.29-1.85)$ & $<0.001^{*}$ & $71(18.25)$ & $1.54(1.27-1.85)$ & $<0.001^{*}$ \\
\hline Adj- $R^{2}$ & & 0.713 & & & 0.762 & \\
\hline
\end{tabular}

Tadjusted for age at interview, BMI, WHR, income, smoking status, alcohol consumption status, physical activity, and familial history of MS; ${ }^{2}$ adjusted for age at interview, BMI WHR, income, alcohol consumption status, physical activity, and familial history of diabetes. ${ }^{*}: \mathrm{P}<0.05$

pleiotropy in this study. Previous studies have suggested biological evidence of pleiotropy for GC/DBP-rs2282679, which influences vitamin D-binding protein; this results in discrepancies in the ratios of free to total plasma $25(\mathrm{OH}) \mathrm{D}$ concentrations and alterations in the feedback control of $25(\mathrm{OH})$ D concentrations [48, 49]. In addition, the vitamin D-binding protein also carries actin, a chemotactic factor implicated in inflammation, that may affect diabetes independent of effects on $25(\mathrm{OH}) \mathrm{D}$ concentrations [50].

Using a genetic variant as a proxy for vitamin D levels has been considered to provide better causal inferences for several reasons. First, unlike vitamin D levels, genetic variants are generally not associated with behavioral, social, and physiological factors that confound the association between vitamin D and MS and its associated

Table 4 Causal coefficients from MR analysis

\begin{tabular}{|c|c|c|c|c|c|c|c|c|}
\hline GRSs & $\begin{array}{l}\text { OR }(95 \% \mathrm{Cl}) \\
\text { for MS }\end{array}$ & $\mathbf{P}$ & $\begin{array}{l}\text { OR }(95 \% \mathrm{Cl}) \\
\text { for T2D }\end{array}$ & $\mathbf{P}$ & $\begin{array}{l}\text { OR }(95 \% \mathrm{Cl}) \\
\text { for abnormal } \\
\text { SBP }\end{array}$ & $\mathbf{P}$ & $\begin{array}{l}\text { OR }(95 \% \mathrm{Cl}) \\
\text { for abnormal } \\
\text { DBP }\end{array}$ & $P$ \\
\hline \multicolumn{9}{|l|}{$\mathrm{GRS}_{\text {synthesis }}$} \\
\hline OR & $\begin{array}{l}1.21(0.88- \\
1.66)\end{array}$ & 0.497 & $\begin{array}{l}1.07(1.01- \\
1.42)\end{array}$ & $0.048^{*}$ & $1.35(0.85-1.84)$ & 0.435 & $1.16(1.02-1.65)$ & $0.003^{*}$ \\
\hline $\begin{array}{l}\mathrm{OR}_{\mathrm{IV}} \text { [per } 25 \mathrm{nmol} / \mathrm{L} \text { decrease } 25(\mathrm{OH}) \mathrm{D} \\
\text { concentration] }\end{array}$ & $\begin{array}{l}0.85(0.56- \\
1.28)\end{array}$ & 0.586 & $\begin{array}{l}1.10(1.02- \\
1.45)\end{array}$ & $0.014^{*}$ & $0.76(0.51-1.31)$ & 0.141 & $1.14(1.03-1.43)$ & $0.019^{*}$ \\
\hline \multicolumn{9}{|l|}{$\mathrm{GRS}_{\text {metabolism }}$} \\
\hline $\mathrm{OR}_{Z Y}$ [per 1 unit higher in GRS] & $\begin{array}{l}1.06(0.79- \\
1.44)\end{array}$ & 0.337 & $\begin{array}{l}0.97(0.66- \\
1.43)\end{array}$ & 0.646 & $0.92(0.73-1.17)$ & 0.652 & $1.13(0.86-1.48)$ & 0.627 \\
\hline $\begin{array}{l}\text { OR } R_{\mathbb{N}}[\text { per } 25 \mathrm{nmol} / \mathrm{L} \text { decrease } 25(\mathrm{OH}) \mathrm{D} \\
\text { concentration] }\end{array}$ & $\begin{array}{l}0.92(0.69- \\
1.22)\end{array}$ & 0.159 & $\begin{array}{l}0.91(0.60- \\
1.36)\end{array}$ & 0.742 & $1.04(0.74-1.45)$ & 0.371 & $0.83(0.62-1.10)$ & 0.579 \\
\hline \multicolumn{9}{|l|}{ GRS $_{\text {combined }}$} \\
\hline OR $R_{Z Y}$ [per 1 unit higher in GRS] & $\begin{array}{l}1.05(0.83- \\
1.32)\end{array}$ & 0.224 & $\begin{array}{l}1.16(0.67- \\
1.51)\end{array}$ & 0.154 & $0.79(0.60-1.02)$ & 0.743 & $1.03(0.73-1.15)$ & 0.085 \\
\hline $\begin{array}{l}\text { OR } \text { I per } 25 \mathrm{nmol} / \mathrm{L} \text { decrease } 25(\mathrm{OH}) \mathrm{D} \\
\text { concentration] }\end{array}$ & $\begin{array}{l}1.04(0.70- \\
1.53)\end{array}$ & 0.457 & $\begin{array}{l}0.92(0.70- \\
1.02)\end{array}$ & 0.082 & $0.88(0.67-1.15)$ & 0.628 & $1.05(1.00-1.49)$ & $0.046^{*}$ \\
\hline
\end{tabular}

Adjusted for age at interview, BMI, WHR, income, smoking status, alcohol consumption status, physical activity and familial history of diabetes. *: P $<0.05$ The association of T2D, MS, and abnormal SBP and DBP with vitamin D-determined GRSs are shown 
diseases. Second, genetic variants associated with vitamin D levels are not influenced by other diseases, and the estimates are therefore less biased. Third, a genetic variant will often reflect exposure throughout the life course and will not change with disease status [51-53]. Finally, using multiple SNPs in different gene loci to index vitamin D levels, this study could minimize the risk of pleiotropic effects; this may be attributed to the fact that the effects of alternative pathways reflected by individual SNPs were strongly diluted when combined in a multi-marker score [54].

A limitation of the present study was the single measurement of vitamin D levels. The lack of $25(\mathrm{OH})$ D GWAS in Asian populations that would allow building of an ethnic-specific genetic score limits the use of MR. Furthermore, the four SNPs explain only approximately $1-4 \%$ of the variance in the $25(\mathrm{OH}) \mathrm{D}$ phenotype [18]. A GRS composed of a larger number of SNPs instrumental for vitamin D levels needs to be calculated to allow for precise estimation based on larger GWAS consortia [55]. Although MR is a potentially powerful technique for strengthening causal inference, several issues could disturb instrumental variable assumptions; these include developmental changes compensating for genetic variation; linkage disequilibrium between genotype and other causal variables; pleiotropy, which refers to a single gene having multiple biological functions [56]; and epigenetic effects, i.e., non-Mendelian heritable changes in gene expression not accompanied by changes in DNA sequence $[21,57]$. This analysis is based on the assumption that the genotype only affects MS and its associated diseases through vitamin D levels.

\section{Conclusions}

The serum 25(OH) D concentration was inversely associated with MS and T2D risk in the rural middle-aged and elderly participants. However, MR analysis demonstrated concordance between genetically determined 25(OH) D using two synthesis SNPs and the risk of T2D and abnormal DBP in middle-aged and elderly participants from eastern rural China. This indicates a risk effect of lower serum $25(\mathrm{OH}) \mathrm{D}$ concentrations on the development of T2D and abnormal DBP. Conversely, genetically determined vitamin $\mathrm{D}$ was not significantly associated with the development of MS; lower vitamin D concentrations are therefore unlikely to have a causal role in the development of MS. Therefore, further trials will be required on vitamin $\mathrm{D}$ supplementation before advocating the use of vitamin D supplements or food fortification for the prevention of MS and T2D.

\section{Abbreviations}

BMI: Body mass index; Cl: Confidence interval; DBP: Diastolic blood pressure; FBG: Fasting blood glucose; GRS: Genetic risk scores; GWAS: Genome-wide association study; HDL-c: High-density lipoprotein cholesterol; HOMR-
IR: Homeostasis model assessment of insulin resistance; IQR: Interquartile range; MR: Mendelian randomization; MS: Metabolic syndrome; ORs: Odds ratios; PCR: Polymerase chain reaction; SBP: Systolic blood pressure; SD: Standard deviation; SNP: Single-nucleotide polymorphism; T2D: Type 2 diabetes; TG: Triglyceride; WC: Waist circumference; WHR: Waist-hip ratio

\section{Supplementary Information}

The online version contains supplementary material available at https://doi. org/10.1186/s12877-021-02307-6.

Additional file 1. Causal coefficients from MR analysis.

\section{Acknowledgments}

We deeply appreciate the participants of the Nantong Chronic Diseases Study in Nantong, China.

\section{Authors' contributions}

$J X, J Y L, Y J G$, and QYL conceived and designed the experiments. SYW, YZ, LWC, JYL, XYZ, and XJW contributed to data collection. JX, YJG, QYL analyzed the data. JX, JYL, SYW, YJG, and QYL drafted the manuscript and approved the final version for submission. All authors read and approved the final manuscript.

\section{Funding}

This work was supported by grants from the National Natural Science Foundation of China (31000539), Jiangsu Provincial Six Talent Peaks for highlevel talents (2016-WSN-098), Nantong Municipal Science and Technology Project (MS12020015, MS22019005, and MS12019033), and the Health Committee of Nantong (2020JCC032).

\section{Availability of data and materials}

The data sets analyzed in this study are available from the corresponding author upon reasonable request.

\section{Declarations}

Ethics approval and consent to participate

The study was conducted according to the guidelines of the Declaration of Helsinki. The study protocols were approved by the Institutional Review Boards of Nantong University and the Nantong Centers for Disease Control. All participants provided written informed consent.

Consent for publication

Not applicable.

\section{Competing interests}

No conflicts of interest, financial or otherwise, are declared by the authors.

\section{Author details}

'Department of Epidemiology and Medical Statistics, School of Public Health, Nantong University, No.9 Seyuan Road, Chongchuan District, Nantong, Jiangsu, P.R. China 226019. 'Department of Endocrinology and Metabolism, Affiliated Hospital of Nantong University, No.20 Xisi Road, Chongchuan District, Nantong, Jiangsu, P.R. China 226001. ${ }^{3}$ Department of Chronic Disease and Prevention, Center for Disease Control and Prevention of Haian, Nantong, Jiangsu, P.R. China 226600

Received: 4 February 2021 Accepted: 25 May 2021

Published online: 29 June 2021

\section{References}

1. Xiao J, Wu C, Xu G, Huang J, Gao Y, Lu Q, et al. Association of physical activity with risk of metabolic syndrome: findings from a cross-sectional study conducted in rural area, Nantong, China. J Sports Sci. 2016;34(19): 1839-48. https://doi.org/10.1080/02640414.2016.1140221.

2. Cheung BM, Wat NM, Man YB, Tam S, Thomas GN, Leung GM, et al. Development of diabetes in Chinese with the metabolic syndrome: a 6-year prospective study. Diabetes Care. 2007;30(6):1430-6. https://doi.org/10.2337/ dc06-1820. 
3. Liu M, Liu SW, Wang LJ, Bai YM, Zeng XY, Guo HB, et al. Burden of diabetes, hyperglycaemia in China from to 2016: findings from the 1990 to 2016, global burden of disease study. Diabetes Metab. 2019;45(3):286-93. https:// doi.org/10.1016/j.diabet.2018.08.008.

4. Han C, Zhang M, Luo X, Wang C, Yin L, Pang C, et al. Secular trends in the prevalence of type 2 diabetes in adults in China from 1995 to 2014: a metaanalysis. J Diabetes. 2017;9(5):450-61. https://doi.org/10.1111/1753-04 07.12440 .

5. Lu J, Wang L, Li M, Xu Y, Jiang Y, Wang W, et al. Metabolic syndrome among adults in China: the 2010 China noncommunicable disease surveillance. J Clin Endocrinol Metab. 2017;102(2):507-15. https://doi.org/1 $0.1210 / j c .2016-2477$

6. Wang Z, Chen Z, Zhang L, Wang X, Hao G, Zhang Z, et al. Status of hypertension in China: results from the China hypertension survey, 20122015. Circulation. 2018;137(22):2344-56. https://doi.org/10.1161/CIRCULA TIONAHA.117.032380.

7. Li W, Song F, Wang X, Wang L, Wang D, Yin X, et al. Prevalence of metabolic syndrome among middle-aged and elderly adults in China: current status and temporal trends. Ann Med. 2018;50(4):345-53. https://doi. org/10.1080/07853890.2018.1464202.

8. Chaudhary N, Nakka KK, Maulik N, Chattopadhyay S. Epigenetic manifestation of metabolic syndrome and dietary management. Antioxid Redox Signal. 2012;17(2):254-81. https://doi.org/10.1089/ars.2011.4387.

9. Prasad G, Bandesh K, Giri A, Kauser Y, Chanda P, Parekatt V, et al. Genomewide association study of metabolic syndrome reveals primary genetic variants at CETP locus in Indians. Biomolecules. 2019;9(8):321. https://doi. org/10.3390/biom9080321.

10. Lu L, Yu Z, Pan A, Hu F, Franco O, Li H, et al. Plasma 25-hydroxyvitamin D concentration and metabolic syndrome among middle-aged and elderly Chinese individuals. Diabetes Care. 2009;32(7):1278-83. https://doi.org/1 $0.2337 / \mathrm{dc} 09-0209$

11. van Schoor NM, Lips P. Worldwide vitamin D status. Best Pract Res Clin Endocrinol Metab. 2011;25(4):671-80. https://doi.org/10.1016/j.beem.2011.06. 007.

12. Dorjgochoo T, Ou Shu X, Xiang Y, Yang G, Cai Q, Li H, et al. Circulating 25hydroxyvitamin $\mathrm{D}$ levels in relation to blood pressure parameters and hypertension in the Shanghai Women's and Men's health studies. Brit J Nutr. 2012;108(3):449-58. https://doi.org/10.1017/S0007114511005745.

13. Renzaho A, Halliday J, Nowson C. Vitamin D, obesity, and obesity-related chronic disease among ethnic minorities: a systematic review. Nutrition. 2011;27(9):868-79. https://doi.org/10.1016/j.nut.2010.12.014

14. Zhang J, Ye J, Guo G, Lan Z, Li X, Pan Z, et al. Vitamin D status is negatively correlated with insulin resistance in Chinese type 2 diabetes. Int J Endocrinol. 2016;2016:1794894.

15. vinh qu c Lu'o'ng $\mathrm{K}$, Nguyễn $\mathrm{L}$. The beneficial role of vitamin $\mathrm{D}$ in obesity: possible genetic and cell signaling mechanisms. Nutr J. 2013;12:89.

16. Han B, Wang X, Wang N, Li Q, Chen Y, Zhu C, et al. Investigation of vitamin $D$ status and its correlation with insulin resistance in a Chinese population. Public Health Nutr. 2017;20(9):1602-8. https://doi.org/10.1017/S136898001 7000490.

17. Ahn J, Yu K, Stolzenberg-Solomon R, Simon KC, McCullough ML, Gallicchio $L$, et al. Genome-wide association study of circulating vitamin D levels. Hum Mol Genet. 2010;19(13):2739-45. https://doi.org/10.1093/hmg/ddq155.

18. Wang T, Zhang F, Richards J, Kestenbaum B, van Meurs J, Berry D, et al. Common genetic determinants of vitamin $D$ insufficiency: a genome-wide association study. Lancet. 2010;376(9736):180-8. https://doi.org/10.1016/ S0140-6736(10)60588-0.

19. Bahrami A, Sadeghnia HR, Tabatabaeizadeh SA, Bahrami-Taghanaki H, Behboodi N, Esmaeili $\mathrm{H}$, et al. Genetic and epigenetic factors influencing vitamin D status. J Cell Physiol. 2018;233(5):4033-43. https://doi.org/10.1002/ jcp.26216.

20. Conen D, Vollenweider P, Rousson V, Marques-Vidal P, Paccaud F, Waeber G, et al. Use of a Mendelian randomization approach to assess the causal relation of gamma-Glutamyltransferase with blood pressure and serum insulin levels. Am J Epidemiol. 2010;172(12):1431-41. https://doi.org/10.1 093/aje/kwq308

21. Smith G, Ebrahim S. 'Mendelian randomization': can genetic epidemiology contribute to understanding environmental determinants of disease? Int J Epidemiol. 2003;32(1):1-22. https://doi.org/10.1093/ije/dyg070.

22. Afzal S, Brondum-Jacobsen P, Bojesen SE, Nordestgaard BG. Vitamin D concentration, obesity, and risk of diabetes: a mendelian randomisation study. Lancet Diabetes Endocrinol. 2014;2(4):298-306. https://doi.org/10.101 6/S2213-8587(13)70200-6.

23. Chen C, Chen Y, Weng P, Xia F, Li Q, Zhai H, et al. Association of 25hydroxyvitamin D with cardiometabolic risk factors and metabolic syndrome: a mendelian randomization study. Nutr J. 2019;18(1):61. https:// doi.org/10.1186/s12937-019-0494-7.

24. Lu L, Bennett DA, Millwood IY, Parish S, McCarthy MI, Mahajan A, et al. Association of vitamin D with risk of type 2 diabetes: a Mendelian randomisation study in European and Chinese adults. PLoS Med. 2018;15(5): e1002566. https://doi.org/10.1371/journal.pmed.1002566.

25. Vimaleswaran KS, Cavadino A, Berry DJ, LifeLines cohort study i, Jorde R, Dieffenbach AK, et al. association of vitamin D status with arterial blood pressure and hypertension risk: a mendelian randomisation study. Lancet Diabetes Endocrinol. 2014;2(9):719-29. https://doi.org/10.1016/S22138587(14)70113-5.

26. Wang $N$, Wang $C$, Chen $X$, Wan $H$, Chen Y, Chen C, et al. Vitamin D, prediabetes and type 2 diabetes: bidirectional Mendelian randomization analysis. Eur J Nutr. 2020;59(4):1379-88. https://doi.org/10.1007/s00394-01901990-X.

27. Ye Z, Sharp S, Burgess S, Scott R, Imamura F, Langenberg C, et al. Association between circulating 25 -hydroxyvitamin D and incident type 2 diabetes: a mendelian randomisation study. Lancet Diabetes Endocrinol. 2015;3(1):35-42. https://doi.org/10.1016/S2213-8587(14)70184-6.

28. Yuan S, Jiang X, Michaelsson K, Larsson SC. Genetic prediction of serum 25Hydroxyvitamin D, calcium, and parathyroid hormone levels in relation to development of type 2 diabetes: a Mendelian randomization study Diabetes Care. 2019;42(12):2197-203. https://doi.org/10.2337/dc19-1247.

29. Holick M. Vitamin D deficiency. N Engl J Med. 2007;357(3):266-81. https:// doi.org/10.1056/NEJMra070553.

30. Alberti KG, Eckel RH, Grundy SM, Zimmet PZ, Cleeman Jl, Donato KA, et al. Harmonizing the metabolic syndrome: a joint interim statement of the international diabetes federation task force on epidemiology and prevention; National Heart, Lung, and Blood Institute; American Heart Association; world heart federation; international atherosclerosis society; and International Association for the Study of obesity. Circulation. 2009;120(16): 1640-5. https://doi.org/10.1161/CIRCULATIONAHA.109.192644.

31. Alberti KG, Zimmet PZ. Definition, diagnosis and classification of diabetes mellitus and its complications. Part 1: diagnosis and classification of diabetes mellitus provisional report of a WHO consultation. Diabet Med. 1998;15(7):539-53. https://doi.org/10.1002/(SICI)1096-9136(199807)15:7<53 9::AID-DIA668>3.0.CO;2-S.

32. Cuellar-Partida G, Williams K, Yazar S, Guggenheim J, Hewitt A, Williams C, et al. Genetically low vitamin $D$ concentrations and myopic refractive error: a Mendelian randomization study. Int J Epidemiol. 2017;46(6):1882-90. https://doi.org/10.1093/ije/dyx068.

33. Burgess $\mathrm{S}$, Thompson S. Use of allele scores as instrumental variables for Mendelian randomization. Int J Epidemiol. 2013;42(4):1134-44. https://doi. org/10.1093/ije/dyt093.

34. Lawlor D, Harbord R, Sterne J, Timpson N, Davey SG. Mendelian randomization: using genes as instruments for making causal inferences in epidemiology. Stat Med. 2008;27(8):1133-63. https://doi.org/10.1002/sim.3 034.

35. Bowden J, Del Greco MF, Minelli C, et al. A framework for the investigation of pleiotropy in two-sample summary data Mendelian randomization. Stat Med. 2017;36(11):1783-802. https://doi.org/10.1002/sim.7221.

36. Leong A, Rehman W, Dastani Z, Greenwood C, Timpson N, Langsetmo L, et al. The causal effect of vitamin D binding protein (DBP) levels on calcemic and cardiometabolic diseases: a Mendelian randomization study. PLoS Med. 2014;11(10):e1001751. https://doi.org/10.1371/journal.pmed.1001 751.

37. Bea JW, Jurutka PW, Hibler EA, Lance P, Martinez ME, Roe DJ, et al. Concentrations of the vitamin D metabolite 1,25(OH)2D and odds of metabolic syndrome and its components. Metabolism. 2015;64(3):447-59. https://doi.org/10.1016/..metabol.2014.11.010.

38. Kayaniyil S, Vieth R, Retnakaran R, Knight J, Qi Y, Gerstein H, et al. Association of vitamin $\mathrm{D}$ with insulin resistance and beta-cell dysfunction in subjects at risk for type 2 diabetes. Diabetes Care. 2010;33(6):1379-81. https://doi.org/10.2337/dc09-2321.

39. Pereira-Santos M, Costa PR, Assis AM, Santos CA, Santos DB. Obesity and vitamin $D$ deficiency: a systematic review and meta-analysis. Obes Rev. 2015;6:341-9. 
40. Afzal S, Bojesen SE, Nordestgaard BG. Low 25-hydroxyvitamin D and risk of type 2 diabetes: a prospective cohort study and metaanalysis. Clin Chem. 2013;59(2):381-91. https://doi.org/10.1373/clinchem.2012.193003.

41. Grant AM, Avenell A, Campbell MK, McDonald AM, MacLennan GS, McPherson GC, et al. Oral vitamin D3 and calcium for secondary prevention of low-trauma fractures in elderly people (randomised evaluation of calcium or vitamin D, RECORD): a randomised placebo-controlled trial. Lancet. 2005; 365(9471):1621-8. https://doi.org/10.1016/S0140-6736(05)63013-9.

42. Pittas AG, Harris SS, Stark PC, Dawson-Hughes B. The effects of calcium and vitamin $\mathrm{D}$ supplementation on blood glucose and markers of inflammation in nondiabetic adults. Diabetes Care. 2007;30(4):980-6. https://doi.org/10.233 7/dc06-1994.

43. Vitezova A, Zillikens MC, van Herpt TT, Sijbrands EJ, Hofman A, Uitterlinden $A G$, et al. Vitamin D status and metabolic syndrome in the elderly: the Rotterdam study. Eur J Endocrinol. 2015;172(3):327-35. https://doi.org/10.1 530/EJE-14-0580

44. Pham TM, Ekwaru JP, Setayeshgar S, Veugelers PJ. The effect of changing serum 25-Hydroxyvitamin D concentrations on metabolic syndrome: a longitudinal analysis of participants of a preventive health program. Nutrients. 2015;7(9):7271-84. https://doi.org/10.3390/nu7095338.

45. Kunutsor SK, Burgess S, Munroe PB, Khan H. Vitamin D and high blood pressure: causal association or epiphenomenon? Eur J Epidemiol. 2014;29(1): 1-14. https://doi.org/10.1007/s10654-013-9874-z.

46. Dorjgochoo T, Delahanty R, Lu W, Long J, Cai Q, Zheng Y, et al. Common genetic variants in the vitamin $D$ pathway including genome-wide associated variants are not associated with breast cancer risk among Chinese women. Cancer Epidemiol Biomark Prev. 2011;20(10):2313-6. https://doi.org/10.1158/1055-9965.EPI-11-0704.

47. Frederiksen B, Kroehl M, Fingerlin T, Wong R, Steck A, Rewers M, et al. Association between vitamin $\mathrm{D}$ metabolism gene polymorphisms and risk of islet autoimmunity and progression to type 1 diabetes: the diabetes autoimmunity study in the young (DAISY). J Clin Endocrinol Metab. 2013; 98(11):E1845-51. https://doi.org/10.1210/jc.2013-2256

48. Powe C, Evans M, Wenger J, Zonderman A, Berg A, Nalls M, et al. Vitamin Dbinding protein and vitamin $\mathrm{D}$ status of black Americans and white Americans. N Engl J Med. 2013;369(21):1991-2000. https://doi.org/10.1056/ NEJMoa1306357.

49. Schoenmakers I, Jones K. Letter to the editor: the effect of genetic factors on the response to vitamin $\mathrm{D}$ supplementation may be mediated by vitamin D-binding protein concentrations. J Clin Endocrinol Metab. 2017; 102(7):2562-3. https://doi.org/10.1210/jc.2017-00666.

50. Zhang J, Kew R. Identification of a region in the vitamin D-binding protein that mediates its C5a chemotactic cofactor function. J Biol Chem. 2004; 279(51):53282-7. https://doi.org/10.1074/jbc.M411462200.

51. Berry D, Vimaleswaran K, Whittaker J, Hingorani A, Hyppönen E. Evaluation of genetic markers as instruments for Mendelian randomization studies on vitamin D. PLoS One. 2012;7(5):e37465. https://doi.org/10.1371/journal.pone. 0037465.

52. Glymour MM, Tchetgen EJ, Robins JM. Credible Mendelian randomization studies: approaches for evaluating the instrumental variable assumptions. Am J Epidemiol. 2012;175(4):332-9. https://doi.org/10.1093/aje/kwr323.

53. Wehby GL, Ohsfeldt RL, Murray JC. 'Mendelian randomization' equals instrumental variable analysis with genetic instruments. Stat Med. 2008; 27(15):2745-9. https://doi.org/10.1002/sim.3255.

54. Davey SG. Random allocation in observational data: how small but robust effects could facilitate hypothesis-free causal inference. Epidemiology. 2011; 22(4):460-3. https://doi.org/10.1097/EDE.0b013e31821d0426.

55. Revez J, Lin T, Qiao Z, Xue A, Holtz Y, Zhu Z, et al. Genome-wide association study identifies 143 loci associated with 25 hydroxyvitamin D concentration. Nat Commun. 2020;11(1):1647. https://doi.org/10.1038/s41467-020-15421-7.

56. Palmer T, Lawlor D, Harbord R, Sheehan N, Tobias J, Timpson N, et al. Using multiple genetic variants as instrumental variables for modifiable risk factors. Stat Methods Med Res. 2012;21(3):223-42. https://doi.org/10.1177/09622 80210394459.

57. Ogbuanu I, Zhang H, Karmaus W. Can we apply the Mendelian randomization methodology without considering epigenetic effects? Emerg Themes Epidemiol. 2009;6(1):3. https://doi.org/10.1186/1742-7622-6-3.

\section{Publisher's Note}

Springer Nature remains neutral with regard to jurisdictional claims in published maps and institutional affiliations.

\section{Ready to submit your research? Choose BMC and benefit from}

- fast, convenient online submission

- thorough peer review by experienced researchers in your field

- rapid publication on acceptance

- support for research data, including large and complex data types

- gold Open Access which fosters wider collaboration and increased citations

- maximum visibility for your research: over $100 \mathrm{M}$ website views per year

At BMC, research is always in progress.

Learn more biomedcentral.com/submissions 